DIRECTEUR DE LA PUBLICATION: Bruno David,

Président du Muséum national d'Histoire naturelle

RÉdACTEUR EN CHEF / EDITOR-IN-CHIEF: Didier Merle

ASSISTANTS DE RÉDACTION / ASSISTANT EDITORS: Emmanuel Côtez (geodiv@mnhn.fr)

Mise EN PAGE / PAGE LAYOUT: Emmanuel Côtez

COMITÉ SCIENTIFIQUE / SCIENTIFIC BOARD:

Christine Argot (Muséum national d'Histoire naturelle, Paris)

Beatrix Azanza (Museo Nacional de Ciencias Naturales, Madrid)

Raymond L. Bernor (Howard University, Washington DC)

Alain Blieck (chercheur CNRS retraité, Haubourdin)

Henning Blom (Uppsala University)

Jean Broutin (Sorbonne Université, Paris)

Gaël Clément (Muséum national d'Histoire naturelle, Paris)

Ted Daeschler (Academy of Natural Sciences, Philadelphie)

Bruno David (Muséum national d'Histoire naturelle, Paris)

Gregory D. Edgecombe (The Natural History Museum, Londres)

Ursula Göhlich (Natural History Museum Vienna)

Jin Meng (American Museum of Natural History, New York)

Brigitte Meyer-Berthaud (CIRAD, Montpellier)

Zhu Min (Chinese Academy of Sciences, Pékin)

Isabelle Rouget (Muséum national d'Histoire naturelle, Paris)

Sevket Sen (Muséum national d'Histoire naturelle, Paris)

Stanislav Štamberg (Museum of Eastern Bohemia, Hradec Králové)

Paul Taylor (The Natural History Museum, Londres)

COUVERTURE / COVER:

Made from the Figures of the article.

Geodiversitas est indexé dans / Geodiversitas is indexed in:

- Science Citation Index Expanded (SciSearch ${ }^{\circledR}$ )

- ISI Alerting Services ${ }^{\circledR}$

- Current Contents ${ }^{\circledR}$ / Physical, Chemical, and Earth Sciences ${ }^{\circledR}$

- Scopus ${ }^{\circledR}$

Geodiversitas est distribué en version électronique par / Geodiversitas is distributed electronically by:

- BioOne ${ }^{\circledR}$ (http://www.bioone.org)

Les articles ainsi que les nouveautés nomenclaturales publiés dans Geodiversitas sont référencés par / Articles and nomenclatural novelties published in Geodiversitas are referenced by:

- ZooBank ${ }^{\circledR}$ (http://zoobank.org)

Geodiversitas est une revue en flux continu publiée par les Publications scientifiques du Muséum, Paris Geodiversitas is a fast track journal published by the Museum Science Press, Paris

Les Publications scientifiques du Muséum publient aussi / The Museum Science Press also publish:

Adansonia, Zoosystema, Anthropozoologica, European Journal of Taxonomy, Naturae, Cryptogamie sous-sections Algologie, Bryologie, Mycologie.

Diffusion - Publications scientifiques Muséum national d'Histoire naturelle

CP $41-57$ rue Cuvier F-75231 Paris cedex 05 (France)

Tél. : 33 (0)1407948 05 / Fax: 33 (0)14079 3840

diff.pub@mnhn.fr / http://sciencepress.mnhn.fr

(C) Publications scientifiques du Muséum national d'Histoire naturelle, Paris, 2020

ISSN (imprimé / print): 1280-9659/ ISSN (électronique / electronic): 1638-9395 


\title{
A new stenochirid lobster (Crustacea, Decapoda, Stenochiridae) from the Early Jurassic of France
}

\author{
Sylvain CHARBONNIER \\ Centre de Recherche en Paléontologie - Paris (CR2P, UMR 7207), \\ (CNRS, MNHN, Sorbonne Université), Muséum national d'Histoire naturelle, \\ case postale 38, 57 rue Cuvier, F-75231 Paris cedex 05 (France) \\ sylvain.charbonnier@mnhn.fr \\ Denis AUDO \\ Yunnan Key Laboratory for Palaeobiology, Yunnan University, \\ North Cuihu road 2\#, 650091 Kunming (China) \\ and MEC International Joint Laboratory for Palaeobiology and Palaeoenvironment, \\ Yunnan University, Kunming (China)
}

Submitted on 16 July 2019 | accepted on 23 July 2019 | published on 26 March 2020

KEY WORDS

France,

Jurassic,

Sinemurian,

Crustacea,

Decapoda,

Astacidea,

Stenochiridae,

new species.

\section{MOTS CLÉS}

France,

Jurassique,

Crustacea,

Decapoda,

Astacidea,

Stenochiridae, espèce nouvelle.
Charbonnier S. \& Audo D. 2020. - A new stenochirid lobster (Crustacea, Decapoda, Stenochiridae) from the Early Jurassic of France. Geodiversitas 42 (7): 93-102. https://doi.org/10.5252/geodiversitas2020v42a7. http://geodiversitas.com/42/7

\section{ABSTRACT}

The marine clawed lobster genus Pseudastacus Oppel, 1861, previously known mainly from the Late Jurassic lithographic limestones of Bavaria (Germany), is herein recorded from the Early Jurassic (Sinemurian, c. 190-199 Ma) of France. A new species, Pseudastacus lemovices n. sp., is introduced. It is the oldest representative of the genus and of the family Stenochiridae Beurlen, 1828.

\section{RÉSUMÉ}

Une nouvelle langoustine sténochiride (Crustacea, Decapoda, Stenochiridae) du Jurassique inférieur de France. Pseudastacus Oppel, 1861, un genre de langoustine connu jusqu’à présent principalement dans les calcaires lithographiques du Jurassique supérieur de Bavière (Allemagne) est ici découvert dans le Jurassique inférieur (Sinémurien, c. 190-199 Ma) de France. Une nouvelle espèce, Pseudastacus lemovices n. sp., est décrite. Il s'agit du plus ancien représentant du genre et de la famille des Stenochiridae Beurlen, 1928. 


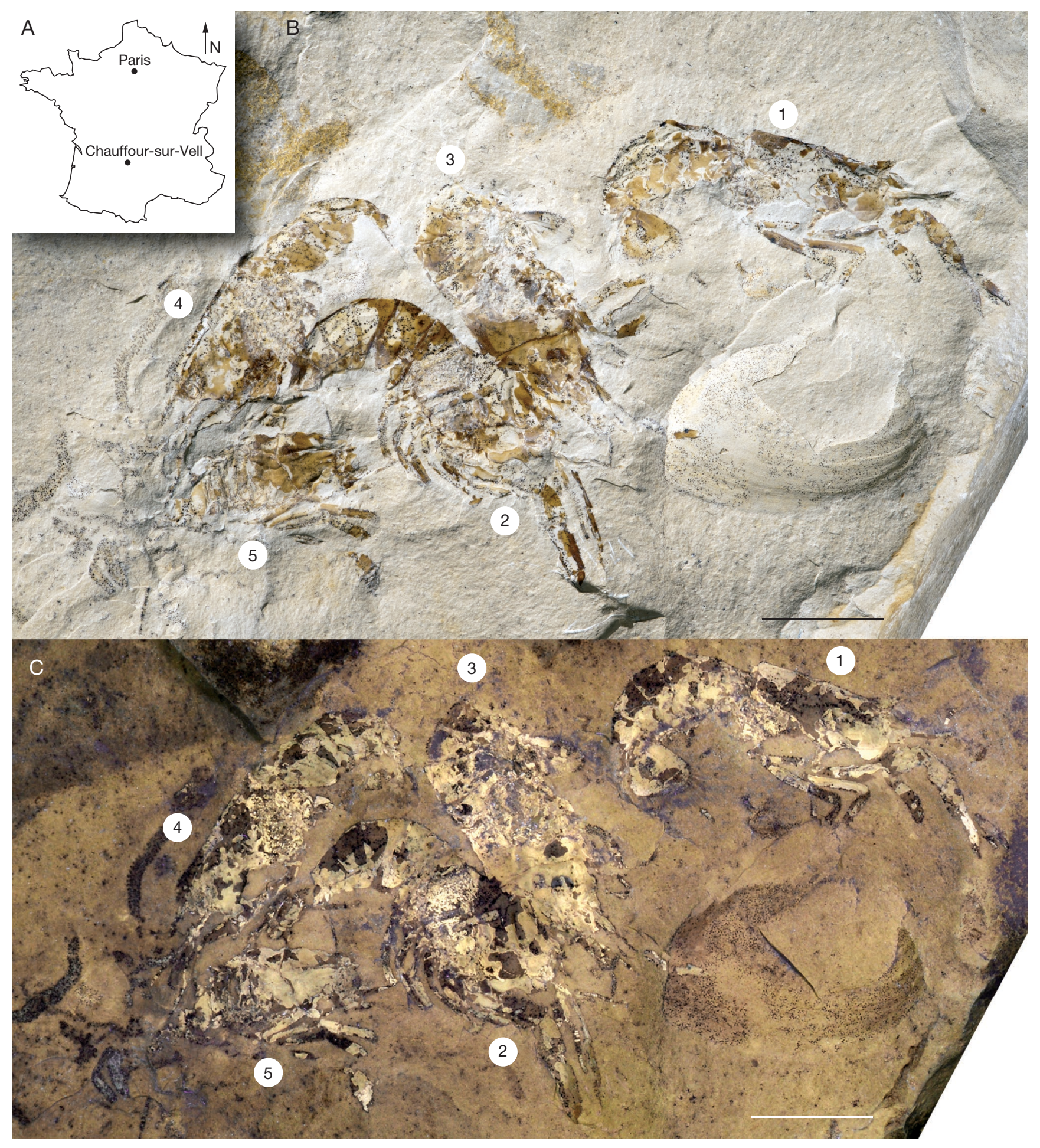

FIG. 1. - Pseudastacus lemovices n. sp. from the Sinemurian of Chauffour-sur-Vell, France: A, map of France with location of the type locality; B-C, slab CNNMP-130 with the association of five preserved specimens, natural light (B) and UV light (C). Abbreviations: 1, holotype CN-NMP-130-1; 2-5, paratypes CNNMP-130-2 to 130-5. Photographs: P. Loubry. Scale bars: $10 \mathrm{~mm}$.

\section{INTRODUCTION}

Stenochirid lobsters (Astacidea, Stenochiroidea, Stenochiridae) are a group of exclusively fossil marine clawed lobsters which members are relatively rare and limited to some Jurassic and Cretaceous outcrops (Table 1). Following the phylogeny and systematics of lobsters proposed by Karasawa et al. (2013), the historical composition of the family evolved including five genera (Stenochirus Oppel, 1861a, Pseudastacus Oppel, 1861b, Palaeophoberus Glaessner, 1932, Tillocheles Woods, 1957, Chilenophoberus Chong \& Förster, 1976). The inclusion of Pseudastacus within the stenochirids is recent and any discovery 
TABLE 1. - List of the members of the family Stenochiridae Beurlen, 1928.

\begin{tabular}{|c|c|c|c|c|c|}
\hline \multirow{2}{*}{$\begin{array}{l}\text { Taxa } \\
\text { Stenochirus Oppel, } 1861\end{array}$} & \multicolumn{2}{|c|}{ Outcrops } & \multicolumn{2}{|c|}{ Ages } & \multirow[t]{2}{*}{ References } \\
\hline & & & & & \\
\hline Stenochirus angutus (Münster, 1839) & Solnhofen & Germany & Tithonian & Late Jurassic & $\begin{array}{l}\text { Münster (1839); Oppel (1861a, 1862); } \\
\text { Garassino \& Schweigert (2006) }\end{array}$ \\
\hline Stenochirus mayeri Oppel, 1862 & Solnhofen & Germany & Tithonian & Late Jurassic & $\begin{array}{l}\text { Oppel (1862); Garassino \& } \\
\text { Schweigert (2006) }\end{array}$ \\
\hline $\begin{array}{l}\text { Stenochirus vahldieki Schweigert, } \\
\text { Garassino \& Riou, } 2006\end{array}$ & $\begin{array}{l}\text { La Voulte-sur- } \\
\text { Rhône }\end{array}$ & -France & Callovian & Middle Jurassic & $\begin{array}{l}\text { Schweigert et al. (2006); } \\
\quad \text { Charbonnier (2009) }\end{array}$ \\
\hline \multicolumn{6}{|l|}{ Pseudastacus Oppel, 1861} \\
\hline $\begin{array}{l}\text { Pseudastacus pustulosus } \\
\text { (Münster, 1839) }\end{array}$ & Solnhofen & Germany & Tithonian & Late Jurassic & $\begin{array}{l}\text { Münster (1839); Oppel (1861b, } \\
\text { 1862); Garassino \& Schweigert } \\
\text { (2006) }\end{array}$ \\
\hline $\begin{array}{l}\text { ?Pseudastacus pusillus } \\
\quad \text { Van Straelen, } 1925\end{array}$ & May-sur-Orne & France & Bajocian & Middle Jurassic & Van Straelen (1925) \\
\hline Pseudastacus lemovices n. sp. & $\begin{array}{l}\text { Chauffour- } \\
\text { sur-Vell }\end{array}$ & France & Sinemurian & Early Jurassic & this work \\
\hline \multicolumn{6}{|l|}{ Palaeophoberus Glaessner, 1932} \\
\hline $\begin{array}{l}\text { Palaeophoberus portlandicus } \\
\text { Roger \& Lapparent, } 1944\end{array}$ & Hannaches & France & Tithonian & Late Jurassic & Roger \& Lapparent (1944) \\
\hline $\begin{array}{l}\text { Palaeophoberus suevicus } \\
\text { (Quenstedt, 1867) }\end{array}$ & Reutlingen & Germany & Aalenian & Middle Jurassic & $\begin{array}{l}\text { Quenstedt (1867); Glaessner } \\
\text { (1932) }\end{array}$ \\
\hline \multicolumn{6}{|c|}{ Chilenophoberus Chong \& Förster, 1976} \\
\hline $\begin{array}{l}\text { Chilenophoberus atacamensis } \\
\text { Chong \& Förster, } 1976\end{array}$ & $\begin{array}{l}\text { Cordillera de } \\
\text { Domeyko }\end{array}$ & Chile & Oxfordian & Late Jurassic & Chong \& Förster (1976) \\
\hline \multicolumn{6}{|l|}{ Tillocheles Woods, 1957} \\
\hline $\begin{array}{l}\text { Tillocheles kaoriae } \\
\text { Yokoi \& Karasawa, } 2000\end{array}$ & Hokkaido & Japan & $\begin{array}{l}\text { Cenomanian, } \\
\text { Turonian }\end{array}$ & Late Cretaceous & Yokoi \& Karasawa (2000) \\
\hline Tillocheles shannonae Woods, 1957 & Queensland & Australia & Albian & Early Cretaceous & Woods (1957) \\
\hline
\end{tabular}

is important to understand the history of this group. After a review of the species included in Pseudastacus, we describe a new species from the Early Jurassic of France and discuss the systematics and age of stenochirid lobsters.

\section{MATERIAL AND METHODS}

The studied material consists of a single slab with five specimens of lobsters (Fig. 1). All are compressed and laterally and/or dorsoventrally flattened on the surface of the slab. The slab was collected during the digging of a pit in the garden of Mrs Boutang and Mr Gomme, at Chauffour-sur-Vell, Corrèze department, France (Fig. 1A). The sediment corresponds to a marine sublithographic limestone of Sinemurian age, possibly early Sinemurian (see Lefavrais-Raymond et al. 1976). After these authors, the limit between the early and late Sinemurian is only cartographic, and the late Sinemurian of the area is well dated by the occurrence of a regional bed yielding the dasycladalean green alga Palaeodasycladus mediterraneus (Pia, 1920).

The sample is exposed at the "L'Espace de découverte de la Faille de Meyssac et de la Pierre" (acronym: CN-NMP), the local museum of Noailhac (Corrèze department) located 10 $\mathrm{km}$ away from the type locality.

The five specimens were studied using a binocular microscope and a camera lucida. The line drawings were made by the first author. Specimens displaying low contrast were imaged by the second author under cross-polarized light (i.e. light source equipped with a linear polarizing filter and camera lens also equipped with a polarizing filter whose optical axis is perpendicular to that of light source polarizer) to reduce reflexion and glare. The same specimens were also imaged: 1) under UV-light for those presenting a UV-yellow fluorescence; and 2) covered in $95 \%$ ethanol to see cuticular remains with a low angle light to reveal relief. The palaeontological arrangement of this study follows the systematics proposed by Karasawa et al. (2013).

\section{SYSTEMATIC PALAEONTOLOGY}

Class MALACOSTRACA Latreille, 1802 Order DECAPODA Latreille, 1802

Suborder PLEOCYEMATA Burkenroad, 1963 Infraorder ASTACIDEA Latreille, 1802

Superfamily STENOCHIROIDEA Beurlen, 1928

Family STENOCHIRIDAE Beurlen, 1928

\section{Genus Pseudastacus Oppel, 1861}

\section{Pseudastacus Oppel, 1861b: 360.}

TYPE SPECIES. - Bolina pustulosa Münster, 1839, by subsequent designation of Glaessner (1929: 350).

INCLUDED SPECIES. - Schweitzer et al. (2010) listed five species included in Pseudastacus: P. hakelensis Fraas, 1878 (Cenomanian, Lebanon), P. minor Fraas, 1878 (Cenomanian, Lebanon), P. mucronatus (Phillips, 1835) (Hauterivian, United Kingdom), P. pusillus Van Straelen, 1925 (Bajocian, France), and P. pustulosus (Münster, 1839) (Tithonian, Germany). 


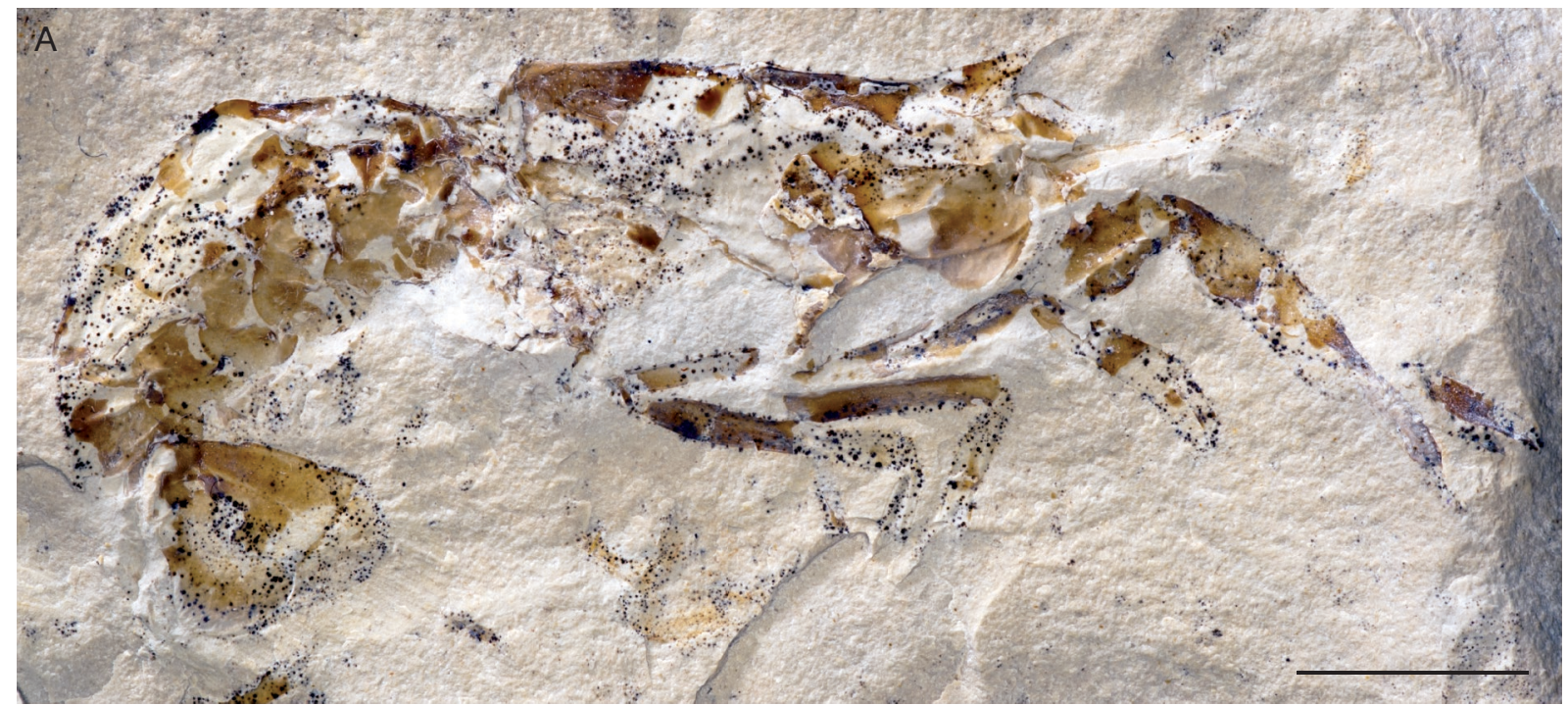

B

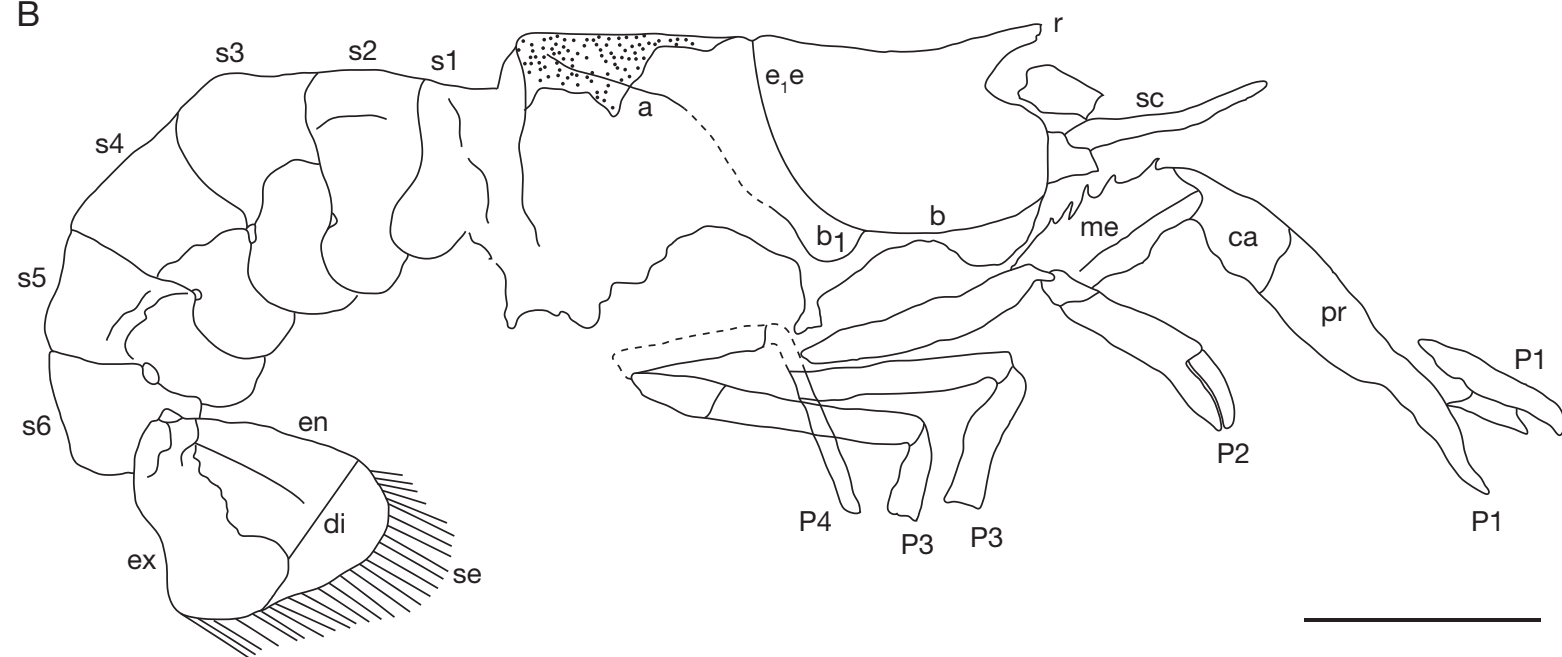

FIG. 2. - Holotype CN-NMP-130-1 of Pseudastacus lemovices n. sp. from the Sinemurian of Chauffour-sur-Vell, France: A, specimen in right lateral view, cross-polarized light; $\mathbf{B}$, interpretative line drawing. Abbreviations: $\mathbf{a}$, branchiocardiac groove; b, antennal groove; $\mathbf{b}_{\mathbf{1}}$, hepatic groove; ca, carpus; di, diaeresis; en, uropodal endopod; ex, uropodal exopod; $\mathbf{e}_{1} \mathbf{e}$, cervical groove; pr, propodus; P1-P4, pereiopods 1 to 4; me, merus; $\mathbf{r}$, rostrum; sc, scaphocerite; se, setae; s1-s6, pleonal somites 1 to 6 . Photograph: D. Audo. Scale bars: $5 \mathrm{~mm}$.

\section{TAXONOMIC COMMENTS}

Pseudastacus hakelensis was moved to Notahomarus by Charbonnier et al. (2017). The type material of Pseudastacus minor is lost (G. Schweigert pers. comm. 2019) and the illustration proposed by Fraas (1878: pl. 4, fig. 2) is not conclusive concerning the taxonomic determination. Indeed, his illustration is relatively strange for the following reasons: 1) either there is a wrong number of pleonal somites (7 instead of 6 excluding the telson), or the first somite is rather large; 2) the rostrum is exceedingly long in comparison with the rest of the carapace; and 3) as the carapace and pleon seem to be in connection suggesting that the specimen was a corpse, the first chelipeds appear strangely placed and should be positioned more anteriorly; in addition, the general morphology of the chelae does not fit with that observed in Pseudascatus.
The type material of Pseudastacus pusillus was destroyed during World War II (see Bigot 1945) and the figure proposed by Van Straelen (1925: pl. 9, fig. 7) is not conclusive. Even if the line drawing provided by Van Straelen (1925: fig. 134) shows the carapace groove pattern, it is difficult to confirm the assignation to Pseudastacus, which was already proposed with a question mark in the original publication.

The type material of Pseudastacus mucronatus corresponds to a fragment of P1 chela figured by Phillips (1829: pl.3, fig. 3) and Phillips (1835: pl. 3, fig. 3), and refigured by Bell (1863: pl. 9, fig. 6). This isolated chela is very massive and the occlusal margins of index and dactylus show very strong tubercles alternating with smallest ones. This general morphology is not consistent with the more elongate and thinner P1 chelae observed in Pseudascatus. Following Woods (1931: 89), this P1 chela might be referred to Hoploparia dentata (Roemer, 1841). 

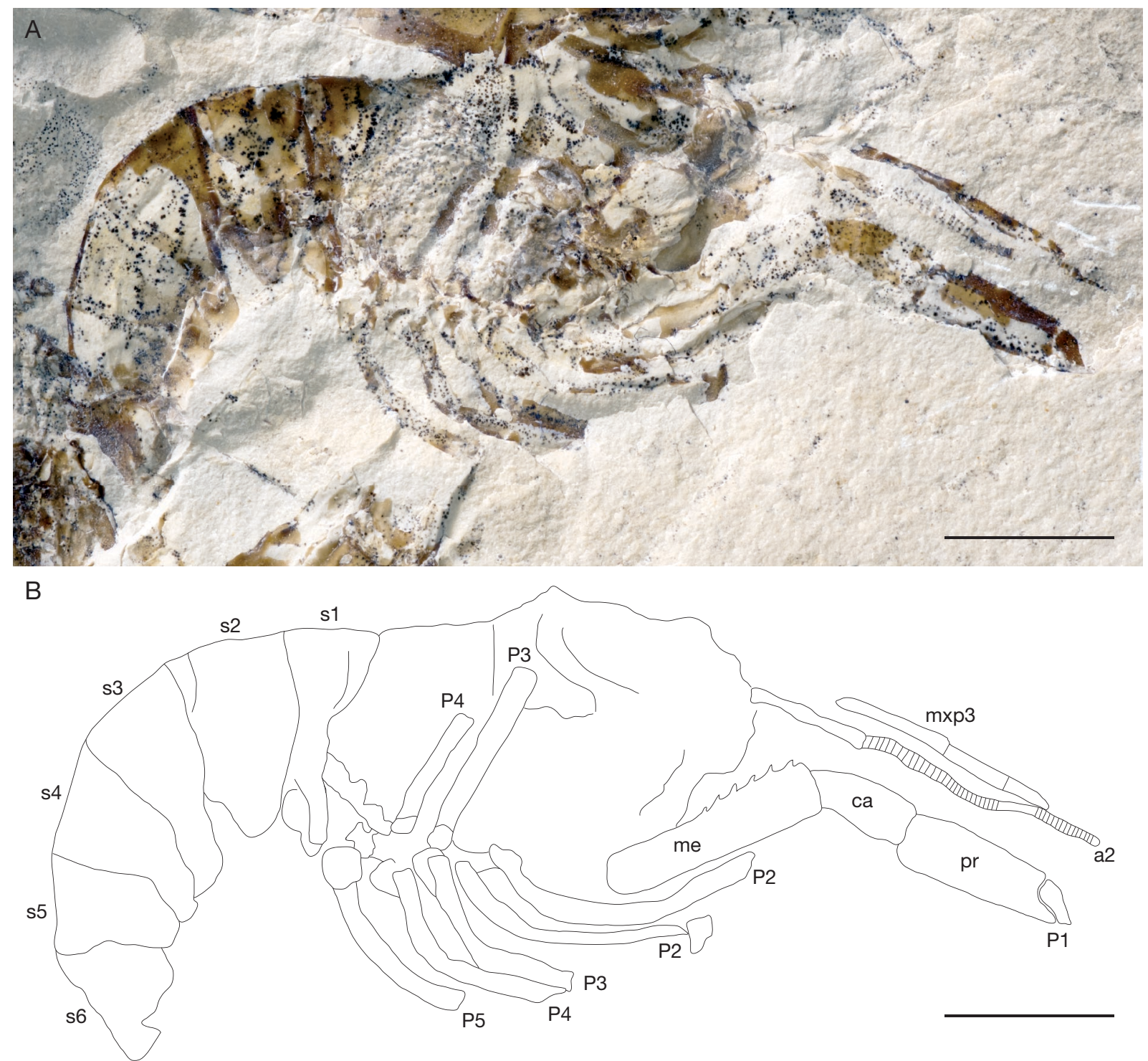

FIG. 3. - Paratype CN-NMP-130-2 of Pseudastacus lemovices n. sp. from the Sinemurian of Chauffour-sur-Vell, France: A, specimen in right lateral/ventral view, cross-polarized light; B, interpretative line drawing. Abbreviations: a2, antenna; ca, carpus; pr, propodus; P1-P5, pereiopods 1 to 5; me, merus; mxp3, third maxilliped; s1-s6, pleonal somites 1 to 6 . Photograph: D. Audo. Scale bars: $5 \mathrm{~mm}$.

\section{Pseudastacus lemovices n. sp.}

(Figs 2-6)

\section{urn:Isid:zoobank.org:act:D58E5862-AD82-4B39-96D4-56BED134F76D}

ETYMOLOGY. - The specific epithet refers to the "Lemovices" (used as a noun in apposition), a Gaulish tribe of Central Europe who established themselves in Limousin and Poitou regions between 700 and $400 \mathrm{BC}$. The type locality Chauffour-sur-Vell is located in Limousin.

TYPe MATERIAL. - Holotype: CN-NMP-130-1.

Paratypes: 4, CN-NMP-130-2 to CN-NMP-130-5. All are preserved in compression at the surface of a single slab of limestone.

Type LOCALITY. — Chauffour-sur-Vell, Corrèze department, Limousin, Nouvelle-Aquitaine region, France.

TYPE AGE. - Early Jurassic, Sinemurian (after Lefavrais-Raymond et al. 1976).

\section{DESCRIPTION}

\section{Carapace}

Subcylindrical carapace (length, excluding rostrum: $c .11 \mathrm{~mm}$; height: $c .6 .5 \mathrm{~mm}$ ); straight dorsal margin; ventral margin poorly preserved; triangular rostrum, elongate, relatively large, with pointed distal extremity, bearing three lateral spines; deep cervical groove, subvertical at level of dorsal margin and ventrally curved before joining concave antennal groove; sinuous branchiocardiac groove joined ventrally to rounded hepatic groove; large and deep orbital incision, ventrally limited by antennal spine.

\section{Pleon}

Somite 1 , smallest than the others; somites 1 to 5 (s1-s5) with rounded pleura, almost straight anteriorly and concave posteriorly; s2-s 5 with longitudinal carina separating tergopleuron from the rest of the tergum; $s 6$ shorter than $s 5$; telson poorly preserved. 

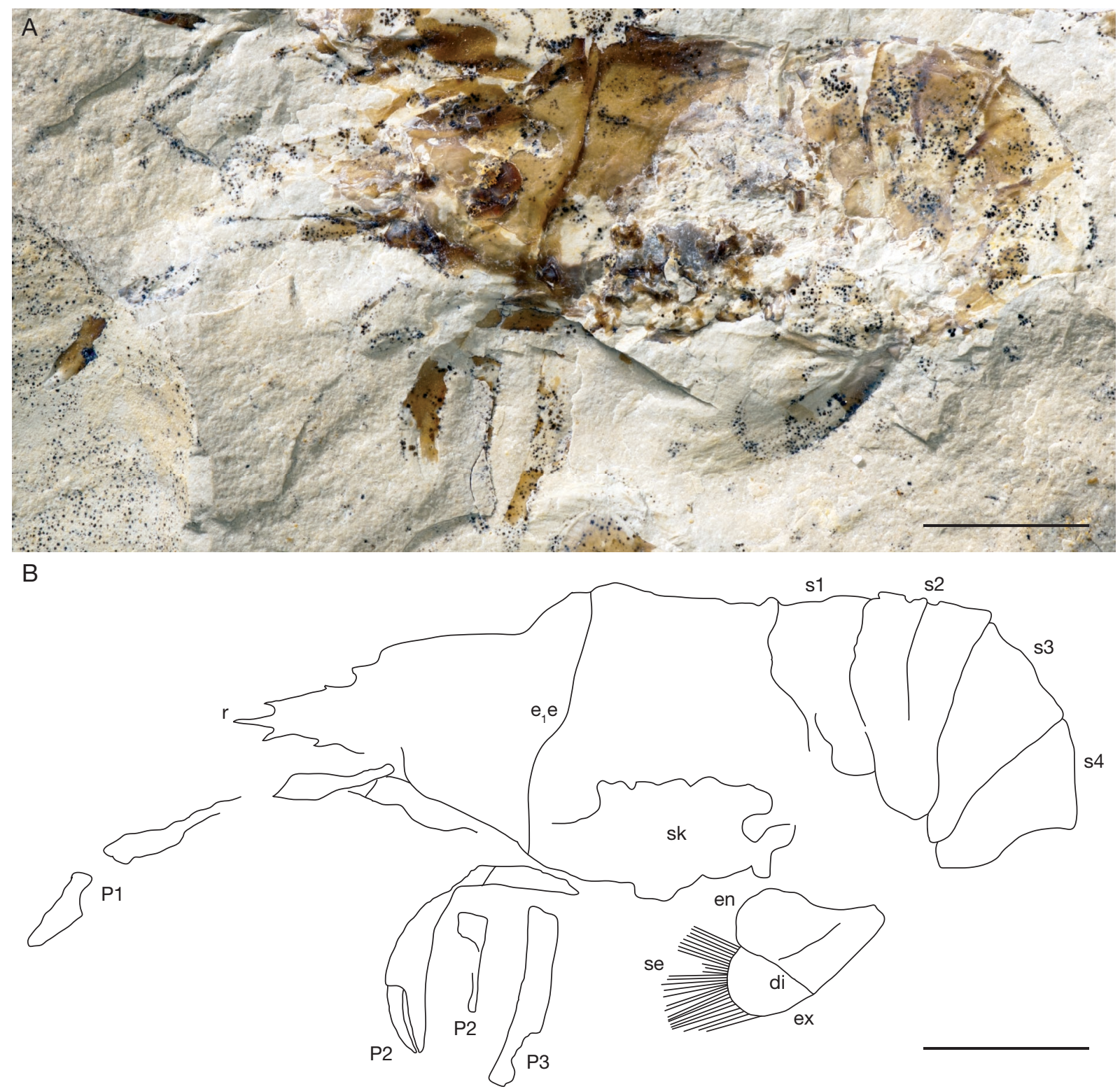

FIG. 4. - Paratype CN-NMP-130-3 of Pseudastacus lemovices n. sp. from the Sinemurian of Chauffour-sur-Vell, France: A, specimen in left lateral/dorsal view, cross-polarized light; B, interpretative line drawing. Abbreviations: di, diaeresis; en, uropodal endopod; ex, uropodal exopod; $\mathbf{e}_{\mathbf{1}}$ e, cervical groove; P1-P3, pereiopods 1 to 3 ; r, rostrum; se, setae; sk, endophragmal skeleton; s1-s4, pleonal somites 1 to 4 . Photograph: D. Audo. Scale bars: 5 mm.

\section{Cephalic appendages}

Rounded eye (preserved only on paratype CN-NMP-130-4); antennulae (a1) poorly preserved, short, with multi-articulated flagella; antennae (a2) composed of elongate antennal peduncle bearing large, elongate, and pointed scaphocerite, and strong multi-articulated flagella; third maxilliped, elongate and smooth;

\section{Thoracic appendages}

Pereiopods 1 to 5 (P1-P5) decreasing in size posteriorly; chelate pereiopods 1 to 3 (P1-P3); P1 larger and longer than P2 and P3; short and stout P1 chela with index and dactylus of equal length, with slightly curved distal extremity and finely serrated occlusal margins; dorsal margin of P1 merus with one longitudinal median row of strong tubercles; P1 carpus and propodus with smooth dorsal margin; small P2 and P3 chelae with index and dactylus of equal length, slightly curved distal extremity; P4 and P5, smallest and smooth, poorly preserved.

\section{Pleonal appendages}

Pleopods not preserved; uropods of equal length, with distal margins fringed by elongate setae; uropodal exopod with longitudinal median carina and straight diaeresis.

\section{Ornamentation}

Carapace uniformly covered by small pits; pereiopods smooth; pleonal somites smooth. Some specimens show a relatively smooth carapace. Thus, the carapace ornamentation is variable in aspect, according to which of the cuticle layers are 


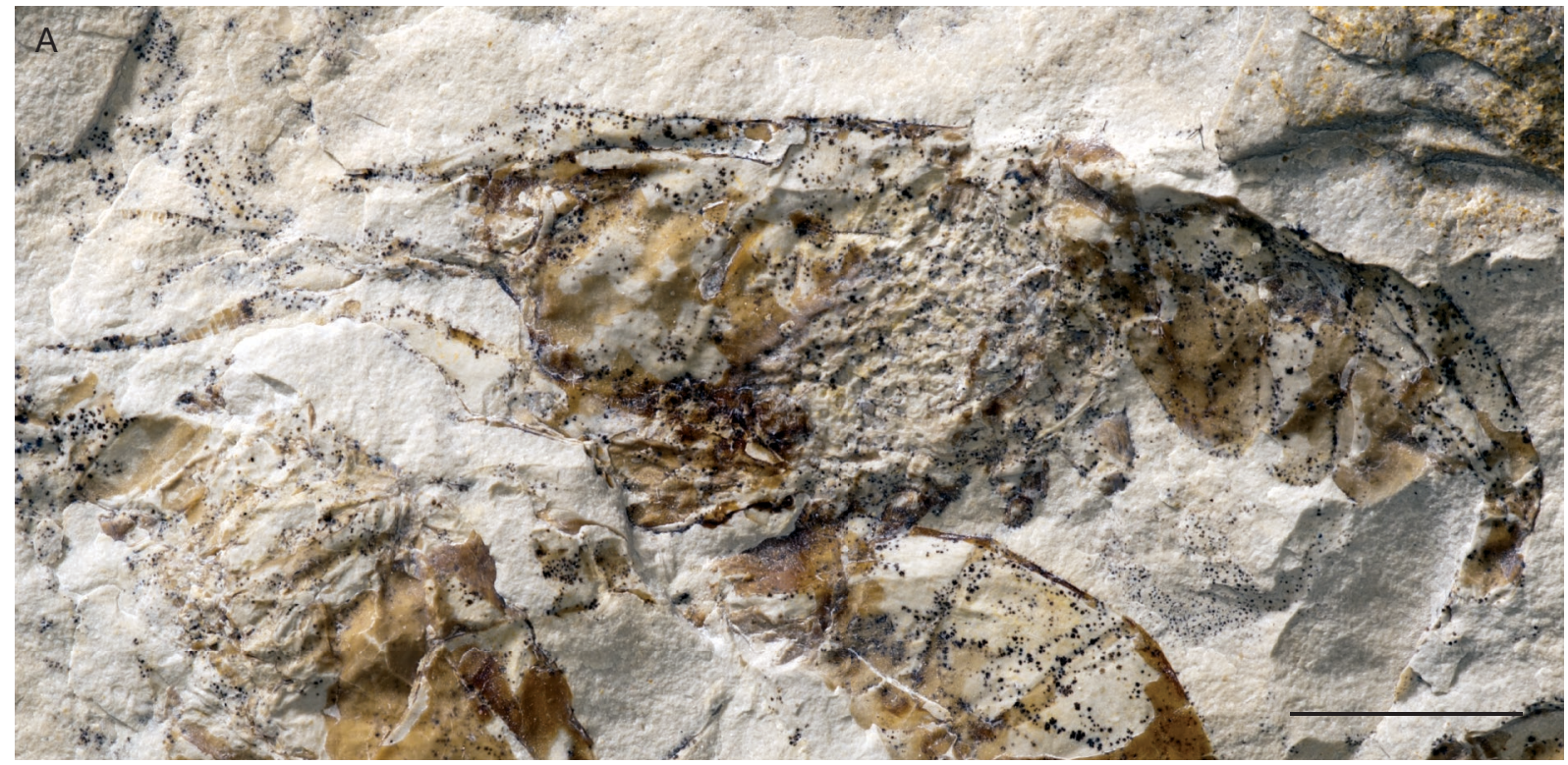

$\mathrm{B}$

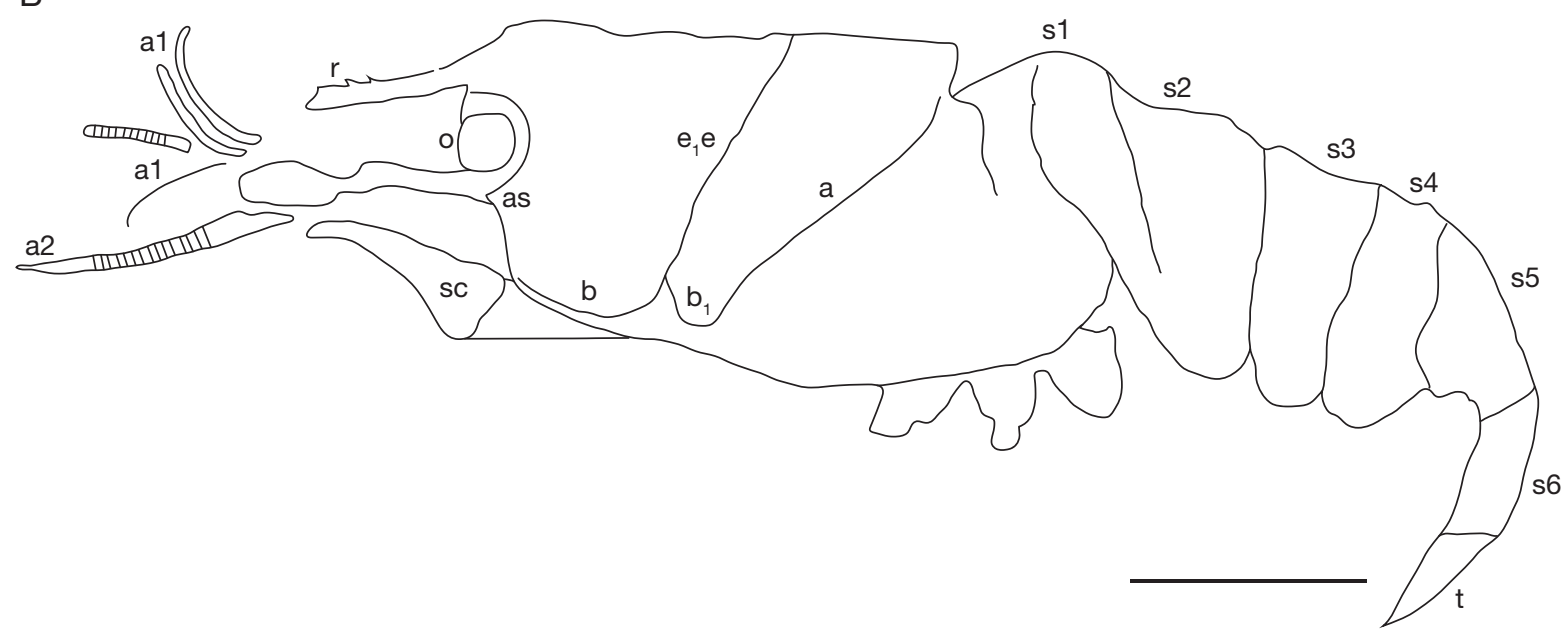

FIG. 5. - Paratype CN-NMP-130-4 of Pseudastacus lemovices n. sp. from the Sinemurian of Chauffour-sur-Vell, France: A, specimen in left lateral view, cross-polarized light; $\mathbf{B}$, interpretative line drawing. Abbreviations: a, branchiocardiac groove; as, antennal spine; a1, antennula; a2, antenna; b, antennal groove; $\mathbf{b}_{\mathbf{1}}$, hepatic groove; $\mathbf{e}_{\mathbf{1}} \mathbf{e}$, cervical groove; o, eye; $\mathbf{r}$, rostrum; sc, scaphocerite; s1-s6, pleonal somites 1 to 6 ; t, telson. Photograph: D. Audo. Scale bars: 5 mm.

preserved: smooth or finely pitted; both aspects may in fact correspond to diverse degrees of abrasion and/or decortication of carapace (similar cases were observed in erymid lobsters: see Charbonnier et al. 2014; Hyžný et al. 2015).

\section{DisCUSSION}

The new species possesses anatomical characters typical of Astacidea: the first three pereiopods are chelate, the first pereiopods are stronger than the others, there are no midlateral hinges between the pleonal somites, the cervical groove is deep and the branchiocardiac groove is oblique. Moreover, following the key proposed by Wahle et al. (2012), the new species is assigned to the family Stenochiridae based upon the following characters: rostrum bearing lateral spines; cervical groove extends transversely from dorsomedian; branchiocardiac groove extends obliquely across lateral portion of carapace; uropodal exopod with diaeresis; pereiopods 2 and 3 bearing very small chelae. More precisely, the new species is assigned to Pseudastacus Oppel, $1861 \mathrm{~b}$ based on the typical groove pattern of the carapace (deep cervical groove crossing dorsal midline; welldeveloped branchiocardiac groove, joined ventrally to hepatic groove), the elongate triangular rostrum with three lateral spines; the short and stout P1 chela. Pseudastacus lemovices n. sp. differs from P. pustulosus by the ornamentation of the carapace (uniformly covered by tubercles in $P$. pustulosus; uniformly covered by pits in P. lemovices n. sp.) and of the first pereiopod (uniformly covered by tubercles in P. pustulosus; smooth in P. lemovices n. sp.).

In addition, this association of five specimens may suggest a mass mortality event linked to an environmental stress (e.g., anoxia, temperature). It may also point to a gregarious behaviour as observed in different extant and fossil lobsters (see Klompmaker \& Fraaije 2012 and references therein). 

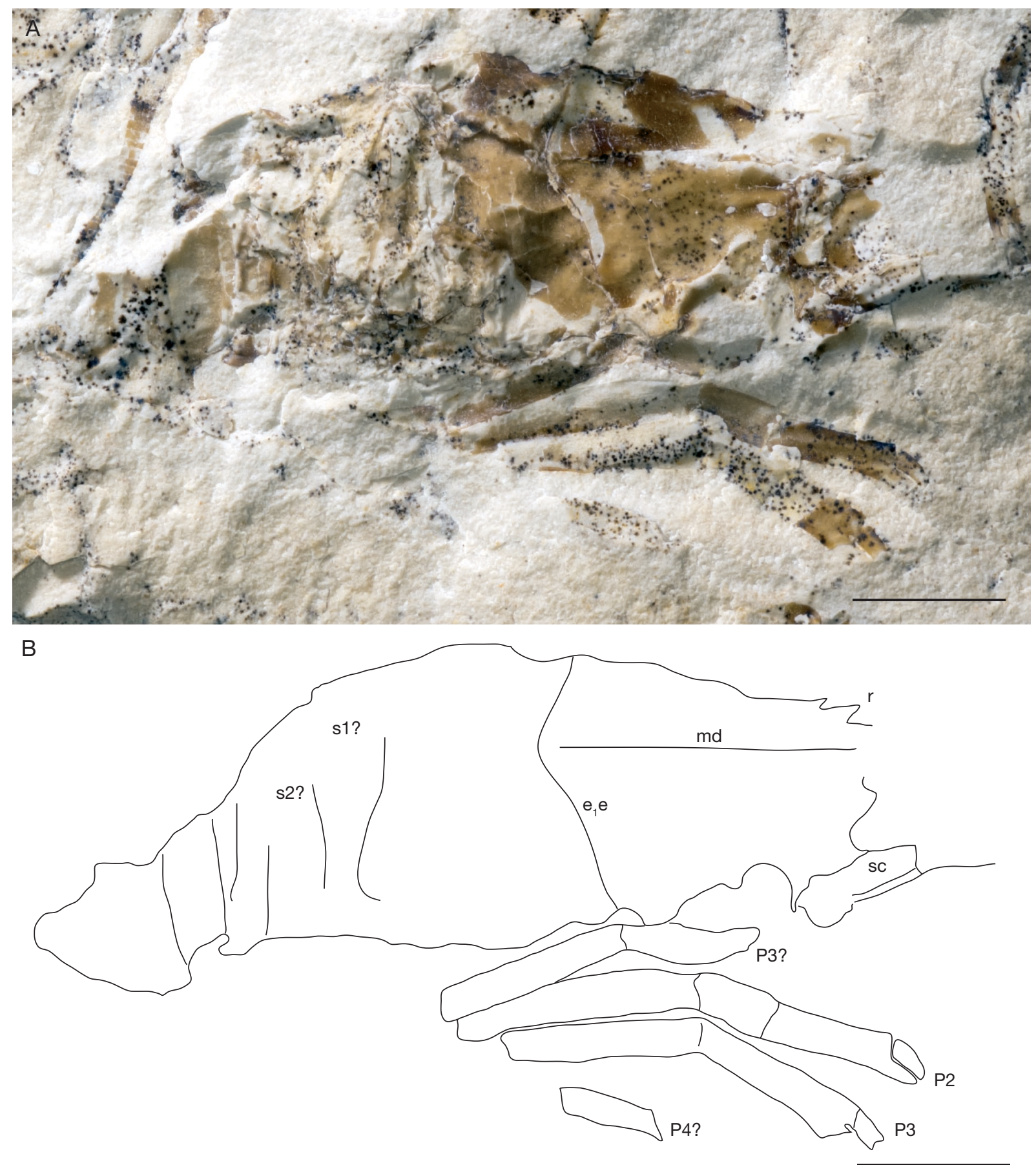

FIG. 6. - Paratype CN-NMP-130-5 of Pseudastacus lemovices n. sp. from the Sinemurian of Chauffour-sur-Vell, France: A, specimen in ventral view, cross-polarized light; B, interpretative line drawing. Abbreviations: $\mathbf{e}_{\mathbf{1}} \mathbf{e}$, cervical groove; md, dorsal midline; P2-P4, pereiopods 2 to 4; r, rostrum; sc, scaphocerite; s1-s2, pleonal somites 1 to 2. Photograph: D. Audo. Scale bars: $5 \mathrm{~mm}$.

\section{CONCLUSIONS}

Pseudastacus Oppel, 1861b, was placed for long time in the family Nephropidae Dana, 1852 as reported by Van Straelen (1925), Beurlen (1928), Glaessner (1929, 1969), and Chong \& Förster (1976). Albrecht (1983) included Pseudastacus in his new family Proastacidae, whereas Tshudy $\&$ Babcock (1997) included it in their new family Chilenophoberidae. Garassino \& Schweigert (2006) preferred to follow Albrecht (1983) considering the analysis of Tshudy \& Babcock (1997) was not founded by a morphological review of the type material, but only on line drawings in literature. Later, De Grave et al. (2009) and Schweitzer et al. (2010) maintained Pseudastacus in the Chilenophoberidae. Finally, Karasawa et al. (2013) proposed to synonymize the Chilenophoberidae with the Stenochiridae Beurlen, 1928, and to place Pseudastacus in this latter family. Here we follow this placement. 
Until now, stenochirid lobsters had only representatives in the Middle Jurassic of France and Germany, in the Late Jurassic of France, Germany and Chile, in the Early Cretaceous of Australia, and in the Late Cretaceous of Japan (for details see Table 1). In conclusion, the Early Jurassic Pseudastacus lemovices n. sp. is the oldest representative of the genus and of the family.

\section{Acknowledgements}

We thank the two reviewers, Alessandro Garassino (Milano Museum) and Günter Schweigert (Stuttgart Museum), for their useful comments on our manuscript. We are pleased to acknowledge Mrs Boutang and Mr Gomme who collected the specimen and donated it to the local museum of Noailhac (Corrèze department, France) and Mr Guy Chantepie, who called our attention to the new specimen. We wish to thank Mr Christian Lassalle, mayor of Noailhac, who made the specimen available and carried it to the MNHN, Paris for our study. We are grateful to Philippe Loubry and Lilian Cazes (UMR 7207 CR2P, MNHN, Paris) for the photographic work.

Denis Audo's research was supported by the China Postdoctoral Science Foundation, Yunnan Province Postdoctoral Science Foundation, NSFC grant 41861134032, and Yunnan Provincial Research Grants 2018FA025 and 2018IA073.

\section{REFERENCES}

Albrecht H. 1983. - Die Protoastacidae n. fam., fossile Vorfahren der Flußkrebse? Neues Jahrbuch für Geologie und Paläontologie, Monatshefte 1983 (1): 5-15.

BELL T. 1863. - A Monograph of the Fossil Malacostracous Crustacea of Great Britain, Part II, Crustacea of the Gault and Greensand. The Palaeontographical Society, London, i-viii, 1-40. https:// doi.org/10.1080/02693445.1863.12027935

Beurlen K. 1928. — Die Decapoden des Schwäbischen Jura mit Ausnahme der aus den oberjurassischen Plattenkalken stammenden. Palaeontographica 70: 115-278.

Bigot A. 1945. - La destruction des collections et des bibliothèques scientifiques de Caen. Bulletin de la Société linnéenne de Normandie, Volume supplémentaire: 1-75.

Charbonnier S. 2009. - Le Lagerstätte de La Voulte : un environnement bathyal au Jurassique. Muséum national d'Histoire naturelle, Paris, 272 p. (Mémoires du Muséum national d'Histoire naturelle ; 199).

Charbonnier S., Audo D., Garassino A. \& HYŽNÝ M. 2017. Fossil Crustacea of Lebanon. Muséum national d'Histoire naturelle, Paris, 252 p. (Mémoires du Muséum national d'Histoire naturelle; 210).

Charbonnier S., Garassino A., Schweigert G., Audo D., FERNANDEZ S. 2014. - New look at the lobster Eryma greppini, OPPEL, 1861 (Crustacea, Decapoda, Erymidae) from the Middle Jurassic of France and Switzerland. Neues Jahrbuch für Geologie und Paläontologie Abhandlungen 272: 331-339. https:// doi.org/10.1127/0077-7749/2014/0411

CHONG G. \& FÖRSTER R. 1976. - Chilenophoberus atacamensis, a new decapod crustacean from the Middle Oxfordian of the Cordillera de Domeyko, northern Chile. Neues Jahrbuch für Geologie und Paläontologie, Monatshefte 1976 (3): 145-156.

De Grave S., Pontcheff N. D., Ahyong S. T., Chan T.-Y., Crandall K. A., Dworschak P. C., Felder D. L., Feldmann R. M., Fransen C. H. M., Goulding L. Y. D., Lemaitre R., Low M. E. Y., Martin J. W., NG P. K. L., Schweitzer C. E.,
TAn S. H., Tshudy D. \& Wetzer R. 2009. — A classification of living and fossil genera of decapod crustaceans. The Raffles Bulletin of Zoology, Supplement 21: 1-109. http://hdl.handle. net/10088/8358

FraAS O. 1878. - Geologisches aus dem Libanon. Jahreshefte des Vereins für Vaterländische Naturkunde in Württemberg 34: 257-391.

Garassino A. \& SchweigerT G. 2006. — The Upper Jurassic Solnhofen decapod crustacean fauna: review of the types from old descriptions. Part I. Infraorders Astacidea, Thalassinidea, and Palinura. Memorie della Società italiana di Scienze naturali e del Museo civico di Storia naturale di Milano 34 (1): 1-64.

Glaessner M. F. 1929. — Crustacea Decapoda, in POMPECKJ J. F. (ed.), Fossilium Catalogus, I: Animalia, Pars 41: 1-464.

GLAESSNER M. F. 1932. - Zwei ungenügend bekannte mesozoische Dekapodenkrebse. Pemphix sueuri (Desm.) und Palaeophoberus suevicus (Quenstedt). Paläontologische Zeitschrift 14: 108-121. https://doi.org/10.1007/BF03041621

Glaessner M. F. 1969. — Decapoda, in Moore R. C. (ed.), Treatise on Invertebrate Paleontology, Part R, Arthropoda 4 (2): 399-533.

HyŽnÝ M., SChlögl J., Charbonnier S., SChweigert G, RulLEAU L. \& GOUTTENOIRE M. 2015 - Intraspecific variation and taphonomy of a new erymid lobster (Crustacea: Decapoda) from the Middle Jurassic of Belmont (Beaujolais, France). Geobios 48: 371-384. https://doi.org/10.1016/j.geobios.2015.07.006

Karasawa H., SChWEITZER C. E. \& FeldmanN R. M. 2013. - Phylogeny and systematics of extant and extinct lobsters. Journal of Crustacean Biology33 (1): 78-123. https://doi.org/10.1163/1937240X-00002111

KlompMaKer A. A. \& FraAije R. H. B. 2012. — Animal Behavior Frozen in Time: Gregarious Behavior of Early Jurassic Lobsters within an Ammonoid Body Chamber. PLoS ONE 7(3): e31893. https://doi:10.1371/journal.pone.0031893

Lefavrais-Raymond A., Feys R., Boissonnas J., Talbert J.-C., Guyonnaud G., Vogt J. \& Raynal J.-P. 1976. - Carte géologique de la France à 1:50 000. Brive-la-Gaillarde. Bureau de recherches géologiques et minières, Orléans, (France), carte 785.

MÜNSTER G. GRAF ZU 1839. - Decapoda Macrura. Abbildung und Beschreibung der fossilen langschwänzigen Krebse in den Kalkschiefern von Bayern. Beiträge zur Petrefaktenkunde 2: 1-88.

Oppel A. 1861a. - Die Arten der Gattungen Glyphea und Pseudoglyphea. Jahreshefte des Vereins für Vaterländische Naturkunde in Württemberg 17: 108-111.

Oppel A. 1861b. - Die Arten der Gattungen Eryma, Pseudastacus, Magila und Etallonia. Jahreshefte des Vereins für Vaterländische Naturkunde in Württemberg 17: 355-361.

OpPel A. 1862. - Ueber jurassische Crustaceen (Decapoda macrura). Paläontologische Mittheilungen aus dem Museum des königlich Bayerischen Staates 1: 1-120.

PHILLIPS J. 1829. - Illustrations of the Geology of Yorkshire. Thomas Wilson and sons, York, 192 p. https://doi.org/10.5962/bhl.title.30592

PHILLIPS J. 1835. - Illustrations of the Geology of Yorkshire. Part 1. The Yorkshire Coast. 2nd Edition. John Murray, London, 184 p. https://doi.org/10.5962/bhl.title.127948

QuenSTEDT F. A. 1867. - Handbuch der Petrefaktenkunde. 2nd edition. Laupp, Tübingen, 982 p. https://gallica.bnf.fr/ark:/12148/ bpt6k97217s

ROGER J. \& LAPPARENT A. F. DE 1944. - Une nouvelle espèce de crustacé décapode Palaeophoberus portlandicus, découverte dans le Portlandien du Pays de Bray. Bulletin de la Société géologique de France 14: 365-374.

Schweigert G., Garassino A. \& Riou B. 2006. — First record of Stenochirus Oppel, 1861 (Crustacea: Decapoda: Stenochiridae) from the Callovian (Middle Jurassic) of La Voulte-sur-Rhône. Neues Jahrbuch für Geologie und Paläontologie, Monatshefte 2006: 65-77. https://doi.org/10.1127/njgpm/2006/2006/65

Schweitzer C. E., Feldmann R. M., Garassino A., KaraSAWA H. \& SCHWEIGERT G. 2010. - Systematic list of fossil decapod crustacean species. Crustaceana Monographs 10: 1-222. https://doi.org/10.1163/ej.9789004178915.i-222 
Tshudy D. \& BABCOCK L. E. 1997. — Morphology-based phylogenetic analysis of the clawed lobsters (family Nephropidae and the new family Chilenophoberidae). Journal of Crustacean Biology 17: 253-263. https://doi.org/10.1163/193724097X00288

Van Straelen V. 1925. - Contribution à l'étude des crustacés décapodes de la période jurassique. Mémoires de la Classe des Sciences de l'Académie royale de Belgique 7: 1-462.

Wahle R. A., Thsudy D., CobB J. S., FACTOR J. \& Jaini M. 2012. Infraorder Astacidea Latreille, 1802 p.p.: The Marine Clawed Lobsters, in SCHRAM F. R., VAupel KLEIN J. C. vON, CHARMANTIER-DAures M., FOReSt J. (eds), Treatise of Zoology - Anatomy, Taxonomy, Biology - The Crustacea. Volume 9, Part B. Eucarida,
Astacidea P. P. (Enoplometopoidea, Nephropoidea), Glypheidea, Axiidea, Gebiidea, and Anomura. Brill, Leiden \& Boston: 3-108. https://doi.org/10.1163/9789047430179_003

Woods H. 1925-1931. - A Monograph of the Fossil Macrurous Crustacea of England. Palaeontographical Society of London, London, $122 \mathrm{p}$.

Woods J. T. 1957. - Macrurous Decapods from the Cretaceous of Queensland. Memoirs of the Queensland Museum 13 (3): 155175. http://www.biodiversitylibrary.org/page/48733649

YOKOI T. \& KARASAWA H. 2000. - Additions to Cretaceous decapod crustaceans from Hokkaido, Japan - Part 2. Chilenophoberidae. Bulletin of the Mizunami Fossil Museum 27: 191-194.

Submitted on 16 July 2019; accepted on 23 July 2019; published on 26 March 2020. 